\title{
PLA Joint Training and Implications for Future Expeditionary Capabilities
}

Mark R. Cozad

RAND Office of External Affairs

CT-451

January 2016

Testimony presented before the U.S.-China Economic and Security Review Commission on January 21, 2016

This product is part of the RAND Corporation testimony series. RAND testimonies record testimony presented by RAND associates to federal, state, or local legislative committees; government-appointed commissions and panels; and private review and oversight bodies. The RAND Corporation is a nonprofit research organization providing objective analysis and effective solutions that address the challenges facing the public and private sectors around the world. RAND's publications do not necessarily reflect the opinions of its research clients and sponsors. RAND ${ }^{\circledR}$ is a registered trademark. 
For more information on this publication, visit www.rand.org/pubs/testimonies/CT451.html

Published by the RAND Corporation, Santa Monica, Calif.

(C) Copyright 2016 RAND Corporation

RAND $^{\circledR}$ is a registered trademark

\section{Limited Print and Electronic Distribution Rights}

This document and trademark(s) contained herein are protected by law. This representation of RAND intellectual property is provided for noncommercial use only. Unauthorized posting of this publication online is prohibited. Permission is given to duplicate this document for personal use only, as long as it is unaltered and complete. Permission is required from RAND to reproduce, or reuse in another form, any of its research documents for commercial use. For information on reprint and linking permissions, please visit www.rand.org/pubs/permissions.html.

The RAND Corporation is a research organization that develops solutions to public policy challenges to help make communities throughout the world safer and more secure, healthier and more prosperous. RAND is nonprofit, nonpartisan, and committed to the public interest.

RAND's publications do not necessarily reflect the opinions of its research clients and sponsors.

\section{Support RAND}

Make a tax-deductible charitable contribution at www.rand.org/giving/contribute

www.rand.org 


\section{Mark R. Cozad ${ }^{1}$ \\ The RAND Corporation}

\section{PLA Joint Training and Implications for Future Expeditionary Capabilities ${ }^{2}$ \\ Before the U.S.-China Economic and Security Review Commission}

January 21, 2016

The development of an effective joint operation capability has been a centerpiece of People's Liberation Army (PLA) modernization objectives for much of the past two decades, particularly after the successes PLA witnessed from U.S. and allied forces operating over Iraq and the former Yugoslavia. The new methods of warfare that PLA observers identified during these operations placed a premium on the efficient use of both information and weapon systems to target an adversary's war-making capacity as opposed to the brute-force conflicts of attrition that characterized military operations in previous generations. The strategic importance placed on gaining superiority in the air, sea, space, and information domains presented an imperative to People's Republic of China (PRC) leaders—reorient the PLA's static, ground-oriented military to become more agile and efficient or fail to keep pace with the demands of the global revolution in military affairs.

In 2001, PLA initiated its program to develop a credible joint operation concept with the Five-Year Plan on Headquarters' Informatization Building, 2001-2005. ${ }^{3}$ This multifaceted effort consisted of conceptual development that brought together a broad body of military science research, technology development, new training guidelines, and operational experimentation. The plan's culmination was marked by two experimentation exercises named Sharp Sword 2005, led by units in the Chengdu and Nanjing Military Regions. Units from the Chengdu Military Region were tasked with exploring new modes of integrated joint training, along with air-land integration between the PLA Army and PLA Air Force (PLAAF). ${ }^{4}$ Units from the Nanjing Military Region were

\footnotetext{
${ }^{1}$ The opinions and conclusions expressed in this testimony are the author's alone and should not be interpreted as representing those of RAND or any of the sponsors of its research. This product is part of the RAND Corporation testimony series. RAND testimonies record testimony presented by RAND associates to federal, state, or local legislative committees; government-appointed commissions and panels; and private review and oversight bodies. The RAND Corporation is a nonprofit research organization providing objective analysis and effective solutions that address the challenges facing the public and private sectors around the world. RAND's publications do not necessarily reflect the opinions of its research clients and sponsors.

2 This testimony is available for free download at http://www.rand.org/pubs/testimonies/CT451.html.

3 "Push Forward Revolution in Military Affairs with Chinese Characteristics, Build Informatized Command Organs-Excerpts of Advanced Typical Experiences from the All-Army Conference on Headquarters Building," Jeifangjun Bao, September 28, 2004, p. 3.

${ }^{4}$ Zhuang Lijun [庄利军] et al., "A Rapidly Expanding Transformation in the Training Domain” [训练领域一场 方兴未艾的变革], Liberation Army Daily [解放军报], February 6, 2006; Cheng Sixun, “Exploration and Practice of Integrated Training of Military Region Units: Part One,” Battle Flag News [战旗报], February, 9
} 
tasked with experimenting on firepower strike coordination, integrated training methods, and interservice coordination mechanisms. ${ }^{5}$ Although this exercise highlighted several shortcomings in PLA's capability to perform integrated joint operations, it marked a significant foundational basis on which follow-on efforts would build. ${ }^{6}$

\section{PLA's Concept of Joint Operations}

PLA's evolving framework for "integrated joint operations" forms the foundation for its current joint operation concept. ${ }^{7}$ In order to achieve success in local wars under informatized conditions, PLA recognizes that it must link military information systems and networks that will enable PRC military planners to fuse "operational strengths" from each of PLA's services. ${ }^{8}$ These integrated joint operations thus rely on a flexible system that permits and enables adjustments and coordination over the entire depth of the battlespace and within all domains as the situation requires. As one senior PLA officer argued in the early conceptual development stages, these types of operations are driven by "the guiding ideology of 'comprehensive supremacy, precision strike, and destruction of systems."'9

PLA's concept of integrated joint operations is linked closely with two other key ideas that drive PLA modernization objectives_- "informatization" and "system-of-systems operations." ${ }^{10}$ The concept of informatization has guided PLA modernization formally for at least the past decade. ${ }^{11}$ PLA considers it to be the essence of integrated joint operations, which rely on information

2006; and Cheng Sixun, "Exploration and Practice of Integrated Training of Military Region Units: Part Two," Battle Flag News [战旗报], February 10, 2006.

${ }^{5}$ Zhuang [庄利军] et al., 2006; Zhang Wenping and Yan Wenbo, "Advance Phase of Second Artillery's Integrated Training Starts-Establishing Steering Group on Integrated Training, Organizing Trial Comprehensive Integration and Integrated Training, Conducting Theoretical Study on Integrated Combat and Training, and Exploring Characteristics and Laws of Integrated Training," Rocket Forces News [火箭兵 报], July 13, 2004, p. 1; and Lu Feng and Ni Menzhi, "Mobile and Camouflaged Launches Using New Equipment Under Complex Weather and Terrain Conditions," People's Front [人民前线], July 28, 2004.

${ }^{6}$ Battle Flag News [战旗报], “An Expedition That Spans History,” March 9, 2006; and Wang Jianmin, "Footprints of the Forerunner," Battle Flag News [战旗报], February 16, 2006.

7 Shou Xiaosong [寿晓松], ed., The Science of Military Strategy [战略学], Beijing: Military Science Press [军 事科学出版社], 2013, p. 125.

${ }^{8}$ Shou, 2013.

${ }^{9}$ Zhan Yu [战玉], “A Study of the Theory of Integrated Joint Operations” [一体化联合作战理论探要], China Military Science [中国军事科学], Issue 6, 2007, pp. 11-21.

${ }^{10}$ Shou, 2013, p. 125.

${ }^{11}$ Ge Dongsheng, ed., On National Security Strategy, Beijing: Military Science Publishing House, 2006, p. 62; Hao Yuqing and Cai Renzhao, eds. Science of Armed Forces Building, pp. 280-282, and Ge, On National Security Strategy, p. 280; and Zhang Yuliang, ed., The Science of Campaigns, Beijing: National Defense University Press, 2006, p. 85. 
networks to integrate and systematize operations designed to obtain information superiority. ${ }^{12}$ From this perspective, informatization underpins most facets of integrated joint operations and serves as a key unifying theme in much of the experimentation that supported development of important new operational concepts, including "three attacks, three defenses," noncontact warfare, and target-centric warfare. Integrated joint operations are considered "the basic form and necessary requirement for informatized war," particularly in terms of ensuring real-time information support, effective precision weapon employment, and a system capable of rapidly deploying and configuring the necessary forces for a range of environments and contingencies. ${ }^{13}$ Furthermore, integrated joint operations entail precision timing for maneuvers, precise position data for fire strikes, and precision support for forces across the battlespace. ${ }^{14}$

PLA's emphasis on the "system-of-systems" concept is based on linking command automation; intelligence, surveillance, and reconnaissance (ISR); precision strike; and rapid mobility in order to rapidly and efficiently strike an enemy's systems composed of vital sites and key nodes. ${ }^{15}$ PLA forces thus seek to employ "combat systems" that optimize operational strengths and the efficiency of critical weapons and capabilities from across PLA's services based on specific operational purposes, usually defined in the context of joint or combined campaigns. ${ }^{16}$ The Campaign Theory Study Guide, an early PLA textbook that address system-of-systems, identified the connection between campaigns and combat systems in the following manner:

Paralyzing the enemy's combat system has become an important means of winning a war. ... Once there are problems in key links of the system, the entire weapon system and combat system will lose its combat effectiveness, or will even become paralyzed. This illustrates that modern campaigns are the confrontation between combat systems.

Advanced weapons and equipment and good strategy and planning both depend upon the integrity and coordination of combat systems.

Therefore, in modern campaigns, attacking and paralyzing key nodes in the enemy's combat system while ensuring the integrity and coordination of one's own combat systems has become an important way of winning. ${ }^{17}$

\footnotetext{
${ }^{12}$ Song Youfa and Hong Yaobin, eds., Integrated Joint Operations Command Headquarters Work, Beijing: Military Science Press, 2005, p. 1.

${ }^{13}$ Zhang, 2006p. 80; and Shou, 2013, p. 127.

${ }^{14}$ Shou, 2013, p. 127.

${ }^{15}$ Shou, 2013, p. 126.

${ }^{16}$ Shou, 2013.

${ }^{17}$ Xue Xinglin [薛兴林], ed., Campaign Theory Study Guide [战役理论学习指南], Beijing: National Defense University Press [国防大学出版社], 2001, p. 66, emphasis added.
} 
This important PLA teaching text—although an early version—highlighted two imperatives for success in future wars that remain central to PLA thinking on system-of-systems operations: the need to build and protect one's own combat system while simultaneously identifying an adversary's critical weaknesses and attacking them. These ideas, developed through PLA's military science research efforts, provide the underpinnings for PLA's most recent joint exercises.

\section{Joint Exercise Objectives}

Since PLA's initial experiments, joint exercise objectives have focused on two broad categories of testing and implementation: enhancing training and preparing for future operations. These essential focus areas-outlined in China's Military Strategy, published in May 2015-are central to what PRC political and military leaders have defined as "preparation for military struggle." ${ }^{18}$ The five areas the strategy identified as driving military preparations include (1) enhancing system-of-systems operations capacity, (2) training in multiple domains and geographic environments, (3) maintaining constant combat readiness, (4) improving military training, and (5) preparing for military operations other than war (MOOTW). ${ }^{19}$ Furthermore, PLA's "integrated combat forces will be employed to prevail in system-vs-system operations featuring information dominance, precision strikes, and joint operations" while promoting the principles of "flexibility, mobility, and self-dependence." ${ }^{20}$ Despite the military strategy's recent publication, PLA joint exercises since 2009 have built on these key themes and served as a centerpiece for PLA capability development.

PLA joint operations training entered a "standardized development" phase as the 10th Five Year Plan ended in 2010, presumably to experiment and test the joint operation concepts and practices that emerged from the Sharp Sword exercises. In 2009, PLA claimed a total of 18 largescale exercises that explored a wide range of joint operation subject matter, including civil-military integration, naval and air force power projection, "systemic operations," joint training methods, and war zone-level command and control. ${ }^{21}$ Three key exercises during 2009 and 2010 Firepower 2009, Stride-2009, and Mission Action 2010—demonstrated PLA's progress in joint operations during the 10th Five Year Plan. More importantly, the underlying themes guiding these exercises and evaluations would serve as the basis for many components of the major exercises seen in the subsequent 11th Five Year Plan.

\footnotetext{
${ }^{18}$ Information Office of the State Council, China's Military Strategy, reprinted by Xinhua, May 26, 2015, p. 11. 
In August 2009, four PLA divisions subordinate to the Shenyang, Lanzhou, Jinan, and Guangzhou Military Regions conducted "the first large-scale, intertheater, live-forces, checkouttype exercises since the founding of the Chinese People's Liberation Army," named Stride2009. ${ }^{22}$ Participating units deployed to a PLA combined tactical training base located outside of their respective military regions. Training subjects ranged from practical evaluations of training practices and procedures to long-range mobility. PLA training methods were further enhanced through the use of dedicated opposition forces and the newly deployed "Army Unit Exercise and Evaluation System."23 Substantively, exercise participants tested new equipment types, including multiple features of the Beidou navigation and positioning system, electronic warfare systems, and psychological warfare support vehicles, among many others. ${ }^{24}$ Stride-2009 also served as a comprehensive test in multiple specialty mobility-related areas, including fuel and material resupply, medical support, war compensation, and political work. ${ }^{25}$

Shortly after Stride-2009 began in October 2009, the PLA General Staff Department's Military Training and Arms Department convened an All-Army Symposium named Firepower-2009, which examined precision strike under informatized conditions. This three-day event brought together PLA experts and scholars tasked with developing new approaches and models for an advanced warfighting concept capable of integrating "precision reconnaissance, precision command, precision firing, and precision evaluation. ${ }^{26}$ In contrast with the evaluation- and test-focused aspects of Stride-2009, Firepower-2009 served almost exclusively as a means for experimentation using demonstrations and working groups composed of military science researchers and operators. The symposium's content clearly reflected PLA thinking on the intersections between joint operation and system-of-systems concepts.

Mission Action-2010 marked the culmination of the 10th Five Year Plan's joint operation training efforts. This exercise involved multiple units from across multiple military regions in a test exercise that focused on transregional maneuver and testing of key operational functions, including joint campaign command, joint firepower strike, comprehensive protection, and precision support. ${ }^{27}$ Overall, the exercise stretched for 20 days and included participants from the Beijing, Chengdu, and Lanzhou Military Regions, along with elements from both the PLAAF and

\footnotetext{
22 Li Yun and Wu Tianmin, "Stride-2009: A Major Exercise Sticking Close to Actual War," Jeifangjun Bao, August 11, 2009, p. 1.

${ }^{23} \mathrm{Li}$ and $\mathrm{Wu}, 2009$.

${ }^{24} \mathrm{Li}$ and $\mathrm{Wu}, 2009$.

${ }^{25} \mathrm{Li}$ and Wu, 2009.

26 "All-Army Artillery and Air Defense Forces' Symposium on Precision Attack Exercises Under Informatized Conditions Concludes," Liberation Army Daily, October 15, 2009.

${ }^{27}$ Cai Pengcheng and Li Yun, "Mission Action-2010 Trans-Military Region Mobile Exercise Concluded," Jeifangjun Bao, November 4, 2010.
} 
PLA Navy (PLAN). Most notably, Mission Action-2010 marked the first time that operational forces crossed military region boundaries to participate in an operationally oriented joint exercise.

\section{Progress and Prospects}

Since the beginning of the 11th Five Year Plan, joint exercises have become even more of a centerpiece in PLA military modernization and experimentation. Primarily, they provide a means by which PRC senior leaders can measure PLA's progress toward achieving its most important modernization objectives. In contrast to the heavy emphasis placed on experimentation and concept development in the major joint exercises during the 9th and 10th Five Year Plans, recent joint exercises have focused on testing and evaluating a wider range of operational missions intended to produce a more flexible, adaptable, and deployable military. At the same time, the integrated joint training methods examined in earlier exercises-along with recognition among senior leaders that training quality needed to be improved overall-have evolved into a broader effort to improve realism and more effectively evaluate unit performance. Although many press reports following these events highlight shortcomings that continue to hinder PLA progress in the field of joint operations, they also portray significant improvements in realism and complexity, as the units involved are placed in much more dynamic scenarios away from their familiar surroundings and with dedicated opposition forces providing more-than-token resistance. Based on these improvements, the capabilities developed during these joint exercises are essential for meeting PLA's objective of being able to fight local wars under the conditions of informatization.

Overall, recent exercises presented scenarios involving large bodies of conventional forces in major conflict scenarios consistent with the "local war" construct, particularly those termed as "medium-scale" and "high-end" local wars. ${ }^{28}$ In multiple cases-Mission Action-2013, Stride-2015, and Firepower-2015 - the exercise scenarios were oriented toward Taiwan. ${ }^{29}$ For instance, during Stride-2015, Taiwan press reported and presented photos showing that PLA was practicing against a mock-up of Taiwan's Presidential Palace. ${ }^{30}$ In cases where the scenarios were neither reported nor self-evident, the exercise content and numbers of units involved represented relatively large-scale conventional operations applicable to either Taiwan scenarios or border conflicts on China's periphery (see table). Accordingly, the progression of these exercises, even when centered on current leadership themes, remained focused on the core elements that PLA

\footnotetext{
${ }^{28}$ Shou, 2013, pp. 99-100.

${ }^{29}$ Kang Yongsheng and Zhang Dianfu, "The 'Mission Action' Military Exercise Has No 'Deep-Level' Intentions," Zhongguo Qingnian Bao, September 27, 2013; “Chen Hu's View on Military Affairs: Detailed Interpretation on 'Mission Action 2013,"' Xinhua, September 27, 2013; and "Chinese Military Exercises Include Simulated Attack on Taiwan," Central News Agency, July 22, 2015.

30 "Chinese Military Exercises Include Simulated Attack on Taiwan," 2015.
} 
leaders have identified as necessary to meet their required modernization objectivesinformatized, system-of-systems-based, high-tempo, multidimensional operations that integrate all PLA combat strengths. ${ }^{31}$

${ }^{31}$ Shou, 2013, pp. 93-98. 
Table: Select PLA Joint Exercises (2009-2015)

\begin{tabular}{|c|c|c|c|c|}
\hline $\begin{array}{l}\text { Exercise } \\
\text { Series }\end{array}$ & $\begin{array}{c}\text { Exercise } \\
\text { Type }\end{array}$ & Main Content & Scenario & Key Points \\
\hline \multicolumn{5}{|l|}{$\begin{array}{l}\text { Stride } \\
\text { (Kua Yue) }\end{array}$} \\
\hline 2009 & $\begin{array}{l}\text { Test and } \\
\text { evaluation }\end{array}$ & $\begin{array}{ll}\text { - } & \text { Long-range mobility } \\
\text { - } & \text { Command and control } \\
\text { - } & \text { Systems integration } \\
\text { - } & \text { Logistics } \\
\text { - } & \text { Political work } \\
\text { - } & \text { Civil-military integration } \\
\text { - } & \text { Training methods } \\
\end{array}$ & $\begin{array}{l}\text { Generic } \\
\text { (viewed as } \\
\text { threat within } \\
\text { region) }\end{array}$ & $\begin{array}{l}\text { Response to inability to deploy } \\
\text { combat forces to relevant } \\
\text { theaters in crises; largest } \\
\text { exercise of its kind at that time. }\end{array}$ \\
\hline 2014 & $\begin{array}{l}\text { Test and } \\
\text { evaluation }\end{array}$ & $\begin{array}{ll}\text { - } & \text { Joint campaign command and } \\
& \text { planning } \\
\text { - } & \text { Training methods } \\
\text { - } & \text { Long-range mobility } \\
\text { - } & \text { Air and space reconnaissance } \\
\text { - Information warfare } \\
\text { - } \\
\text { - } \text { Sir and long-range firepower strikes } \\
\text { - } \quad \text { Civil-military integration }\end{array}$ & Generic & $\begin{array}{l}\text { Opposition force won six of } \\
\text { seven confrontations; after- } \\
\text { action analysis revealed } \\
\text { commanders had not placed } \\
\text { enough emphasis on key } \\
\text { operational elements; weak } \\
\text { command and organization. }\end{array}$ \\
\hline 2015 & $\begin{array}{l}\text { Test and } \\
\text { evaluation }\end{array}$ & $\begin{array}{ll}\text { - } & \text { Long-range mobility } \\
\text { - } & \text { Training methods } \\
\text { - } & \text { Joint operations } \\
\text { - } & \text { Air-land integration } \\
\text { - } & \text { Special operations } \\
\text { - } & \text { Urban combat } \\
\text { - } & \text { Night tactics } \\
\text { - } & \text { Reconnaissance } \\
\text { - } & \text { Electronic warfare } \\
\end{array}$ & Taiwan & $\begin{array}{l}\text { Opposition force won all } 29 \\
\text { engagements; lacked } \\
\text { experience operating in } \\
\text { unfamiliar terrain; poor } \\
\text { coordination and information- } \\
\text { sharing between units and } \\
\text { service arms. }\end{array}$ \\
\hline \multicolumn{5}{|l|}{$\begin{array}{l}\text { Firepower } \\
\text { (Hue Li) }\end{array}$} \\
\hline 2009 & $\begin{array}{l}\text { Experimental } \\
\text { (symposium) }\end{array}$ & $\begin{array}{ll}\text { - } & \text { Reconnaissance } \\
\text { - } & \text { Command and control } \\
\text { - } & \text { Precision strike } \\
\text { - } & \text { Training methods } \\
\text { - } & \text { System-of-systems } \\
\end{array}$ & Generic & $\begin{array}{l}\text { Likely a culmination of } \\
\text { theoretical work performed on } \\
\text { joint firepower strikes and } \\
\text { integrated joint operations. }\end{array}$ \\
\hline 2014 & $\begin{array}{l}\text { Tactical training } \\
\text { exercise }\end{array}$ & $\begin{array}{ll}\text { - } & \text { Long-range mobility } \\
\text { - } & \text { Rapid response } \\
\text { - } & \text { Counter nuclear, biological, and } \\
\text { - } & \text { chemical warfare } \\
\text { - } & \text { Reconnaissance } \\
\text { - } & \text { Information operations } \\
\text { - } & \text { Firepower strikes } \\
\text { - } & \text { Training methods }\end{array}$ & Generic & $\begin{array}{l}\text { Focused on "actual combat" } \\
\text { and improving joint operations; } \\
\text { poor intelligence fusion; target } \\
\text { acquisition under } \\
\text { electromagnetic conditions. }\end{array}$ \\
\hline 2015 & $\begin{array}{l}\text { Test and } \\
\text { evaluation }\end{array}$ & $\begin{array}{ll}\text { - } & \text { Combined arms } \\
\text { - } & \text { Long-range mobility } \\
\text { - } & \text { Command and control } \\
\text { - } & \text { Maneuver } \\
\text { - } & \text { Firepower strikes } \\
\text { - } & \text { Systems integration } \\
\text { - } & \text { Dynamic targeting } \\
\text { - } & \text { Damage assessment } \\
\text { - } & \text { Training methods }\end{array}$ & Taiwan & $\begin{array}{l}\text { Slow decisionmaking and } \\
\text { coordination; poor training for } \\
\text { some units prior to exercise; } \\
\text { communication issues in } \\
\text { complex environment. }\end{array}$ \\
\hline
\end{tabular}




\begin{tabular}{|c|c|c|c|c|}
\hline $\begin{array}{l}\text { Exercise } \\
\text { Series }\end{array}$ & $\begin{array}{c}\text { Exercise } \\
\text { Type } \\
\end{array}$ & Main Content & Scenario & Key Points \\
\hline \multicolumn{5}{|c|}{$\begin{array}{l}\text { Mission Action } \\
\text { (Shi Ming) }\end{array}$} \\
\hline 2010 & $\begin{array}{l}\text { Test and } \\
\text { evaluation }\end{array}$ & $\begin{array}{ll}\text { - } & \text { Long-range mobility } \\
\text { - } & \text { Power projection (PLAN/PLAAF) } \\
\text { - } & \text { Joint campaign command } \\
\text { - } & \text { Joint firepower strike } \\
\text { - } & \text { Comprehensive protection } \\
\text { - } & \text { Precision support }\end{array}$ & Generic & $\begin{array}{l}\text { First-time use of integrated } \\
\text { command platform; } \\
\text { information confrontation in all } \\
\text { phases of exercises; } \\
\text { commanders lacked } \\
\text { knowledge of information- } \\
\text { based system-of-systems } \\
\text { operations. }\end{array}$ \\
\hline 2013 & & $\begin{array}{ll}\text { - } & \text { Amphibious operations } \\
\text { - } & \text { Long-range mobility/ power } \\
\text { - } & \text { Frojection } \\
\text { - } & \text { Comprepower strike } \\
\text { - } & \text { Protection } \\
\text { - } & \text { Civil-military integration } \\
\text { - } & \text { Air defense } \\
\text { - } & \text { Training methods }\end{array}$ & Taiwan & $\begin{array}{l}\text { Commanders continued to rely } \\
\text { on old concepts; command } \\
\text { staffs failed to use information } \\
\text { systems effectively; showed } \\
\text { limited adaptability. }\end{array}$ \\
\hline \multicolumn{5}{|c|}{$\begin{array}{l}\text { Joint Action } \\
\text { (Lian He) }\end{array}$} \\
\hline 2014 & $\begin{array}{l}\text { Tactical training } \\
\text { exercise }\end{array}$ & $\begin{array}{l}\text { - Joint operations } \\
\text { - } \text { Theater command and control } \\
\text { - Reconnaissance } \\
\text { - Information operations } \\
\text { - Training methods } \\
\text { - Logistics } \\
\text { - Ground-air integration } \\
\text { - } \quad \text { Civil-military integration } \\
\end{array}$ & Generic & $\begin{array}{l}\text { Problems with air-ground } \\
\text { integration; lack of standards } \\
\text { for joint planning; problems } \\
\text { coordinating firepower strikes; } \\
\text { recognized need to improve } \\
\text { mechanism for targeting. }\end{array}$ \\
\hline 2015 & $\begin{array}{l}\text { Mission- } \\
\text { oriented joint } \\
\text { exercise }\end{array}$ & $\begin{array}{l}\text { - Joint command } \\
\text { - Urban combat } \\
\text { - Tactical joint operations } \\
\text { - Joint logistics } \\
\text { - Equipment support } \\
\text { - Sea-air-land integration } \\
\text { - Information operations } \\
\text { - Maritime operations } \\
\text { - Training methods } \\
\text { - Reconnaissance }\end{array}$ & Generic & $\begin{array}{l}\text { Stressed training commanders } \\
\text { with emphasis on joint } \\
\text { planning; attempted to build } \\
\text { flexibility and adaptability } \\
\text { among staffs; encouraged } \\
\text { coordination between PLA } \\
\text { services. }\end{array}$ \\
\hline
\end{tabular}

Training objectives for these exercises varied, but they focused largely on the key themes underpinning PLA modernization initiatives. ${ }^{32}$ Probably the most significant theme involved in each event dealt with long-range mobility and logistics support. Stride-2009 set a precedent for deploying units from multiple military regions to distant training facilities. Subsequent exercises built on this initial event with larger and more-complex deployments. Stride-2009 involved approximately 50,000 troops from four military regions—Lanzhou, Jinan, Shenyang, and Guangzhou—deployed to regional training bases that were on average 1,200 km from their home

\footnotetext{
${ }^{32}$ For a more detailed breakout of exercise content, scenarios, and issues involved with each exercise, see the included table.
} 
bases. ${ }^{33}$ A main exercise component involved testing PLA's military logistics system, particularly local logistics and supply procurement, use of civilian air and rail transportation assets, and coordination of bulk materials among PLA and local logistics departments. ${ }^{34}$ By comparison, a single phase of the Mission Action-2013 exercise involved approximately 40,000 troops maneuvering up to $30,000 \mathrm{~km}$ to the designated training range. ${ }^{35}$ Most notably, units deployed by means of military and civilian motorized, rail, maritime, and air transportation, simultaneously having to conduct "anti-reconnaissance, anti-air raid, anti-jamming, and anti-harassment drills" while en route to their designated training centers. ${ }^{36}$ Subsequent exercises involved similar numbers and complexity and placed significant emphasis on long-range mobility in the exercise objectives. Firepower-2015 involved units from all seven military regions, and Joint Action-2015 consisted of five phases involving units from the Nanjing, Guangzhou, Chengdu, and Lanzhou Military Regions, along with PLAN and PLAAF. ${ }^{37}$

Another major point of emphasis for PLA's joint exercises is improving the ability of commanders and their staffs to plan and direct operations involving forces from multiple services and arms in unfamiliar, complex environments. Toward this end, PLA leaders have attempted to increase the realism and rigor involved in joint exercises by employing opposition forces, realistic scenarios that reflect potential future combat scenarios, and rigorous evaluation systems. During Stride2014 and Stride-2015, opposition forces—referred to as "blue force" units in the PLA—won an overwhelming number of their confrontations against participating units. ${ }^{38}$ In addition, the use of blue force units when coupled with long-distance deployments to unfamiliar training facilities provided commanders participating in all joint exercises with an opportunity to confront unfamiliar situations. These conditions stressed command staffs' abilities to manage information, develop situational awareness, and direct the full-range of capabilities of the units participating in the exercises.

In addition to these two central themes in PLA joint training, these major joint exercise series contained a wide range of critical themes, including joint firepower strikes, reconnaissance and

\footnotetext{
${ }^{33}$ Kent Ewing, "China's War Games Unnerve Neighbors," Asia Times, August 18, 2009.

${ }^{34}$ Liu Mingxue, "PLA Modern Logistics System Develops Rapidly," Jeifangjun Bao, September 18, 2009; Hu Qiyin and Sun Kedong, "Military-Local Cooperation: Joint Training and Joint Support," Guangzhou Zhanshi Bao, September 17, 2009, p. 2; and Gai Xuhui and Tan Changjun, "Advance Detachment of Air Transportation," Jeifangjun Bao, September 2, 2009.

${ }^{35}$ Wang Yushen, "PLA Will Carry Out 'Mission Action-2013' Exercise," Jeifangjun Bao, September 9, 2013.

${ }^{36}$ Wang, 2013.

37 "PLA Holds Series Exercise to Beef Up Combat Power in Joint Operations," Jeifangjun Bao, October 14, 2015; and "Firepower-2015' Trans-Military Region Military Exercise Kicked Off," Jeifangjun Bao, May 5, 2015.

${ }^{38}$ Lan Ying, "What Signal Does the Series of 10 Military Exercises Send?" Zhongguo Qingnian Bao, July 25, 2014; and Fang Yongzhi, "The Duty of the Blue Forces Is to Tell the Red Forces What Kind of War to Fight in the Future," Zhongguo Qingnian Bao, July 24, 2015.
} 
intelligence, special operations forces, amphibious operations, urban combat, and electronic warfare, among many other training subjects. During the 13th Five Year Plan, PLA will continue to build on achievements from the 12th Five Year Plan, while emphasizing improved training methods and exercise scenarios. To this point, PLA joint operation development has followed a consistent path of concept development, experimentation, and test and evaluation involving all parts of PLA. With the recent guidance outlined in China's Military Strategy, PLA has been given a clear set of guidelines for those areas most critical to its future concept of joint operations.

PLA joint capability development, as reflected in major exercises, has met with multiple successes. Likewise, this process has also highlighted a series of long-standing problems that PRC military leaders recognize as major obstacles to future operational success. In broad terms, the complexity involved in PLA exercises has improved markedly since the set-piece, large-scale exercises performed in the late 1990s and early 2000s. Most notably, exercises in which units deployed to dedicated training centers far away from their home garrisons, bases, and ports have emphasized the need for rapidly moving over long distances to respond to crisis situations. Furthermore, as units deployed, they were tasked with integrating new weapon systems, reconnaissance capabilities, and command and control systems in scenarios that made regular use of blue forces, further lending realism to the training.

As PLA has improved in many areas, these exercises have highlighted a series of shortcomings in their after-action review process. One of the most noteworthy challenges is in the experience and decisionmaking of PLA commanders and staffs. In almost all of these exercises, PLA press reporting highlighted cases in which PLA commanders were not well-versed in the wide range of capabilities at their disposal, failed to coordinate and share information among the units under their command, and demonstrated weak command and organization skills. ${ }^{39}$ Furthermore, the consistent difficulty that PLA units faced when confronted with blue forces highlights potential operational shortcomings when faced with situations approximating unfamiliar foreign capabilities. $^{40}$

\footnotetext{
${ }^{39}$ There are numerous articles that discuss those shortcomings identified in a given exercises or those which the training event is designed to address. The following sources provide representative examples: Xue Xinglin, "Battlefields in the Eyes of Military Experts: Records of Interviews with Members of the 'Stride2015 Zhurihe J' Exercise Observation Team of the National Defense University," Guangzhou Zhanshi Bao, October 12, 2015, p. 3; Fang Yongzhi, "Numerous New Changes in This Year's 'Stride' Series Exercises," Zhongguo Qungnian Bao, June 19, 2015; Liu Qiang, “The 'Firepower-2015 Qingtongxia A' Exercise Is Conducted in a Strong Combat-Realistic Way; Artillery Groups Involved in the Exercise Are Given Comprehensive Tactical Tests with Live Ammunition Under the Condition of Live Force Confrontation," Jeifangjun Bao, July 19, 2015, p. 1; and Li Dayong and Li Xianghui, "Shenyang Military Region 'Joint-2013' Live Exercise Commences-Nearly 20,000 Personnel Participate in Exercise, The Purpose Is to Explore Campaign and Tactics Integrated Exercise Model, Advance In-Depth Jointness Among Ground and Air Units," Jeifangjun Bao, October 21, 2013, p. 2.

${ }^{40}$ At this point, it is uncertain the extent to which PLA blue-force units attempt to emulate U.S. or other advanced military capabilities and tactics or whether these units are selected based on their elite status.
} 
Based on the sources and detail of available reporting, it would be easy to overstate either the improvements or the continued shortcomings in PLA joint operations capability. Accordingly, due to the limited detail contained in reports on PLA joint capability development, overarching assessments should be caveated with an acknowledgement of the limitations of the available evidence. Regardless, the joint exercises that have taken place over the past two Five Year Plans represent significant moves forward from those exercises convened prior to 2005. PLA has gone to great lengths to improve realism and build real capability. Similarly, PLA continues to highlight persistent problems in command, integration, and planning. Therefore, the improved realism in joint exercises is, in part, designed to alleviate a broader lack of combat experience within PLA; however, the degree to which PRC's military science-based approach to capability development can meet its most difficult objectives remains uncertain.

\section{Implications for Expeditionary and Force Projection Operations}

To date, none of PLA's joint exercises has addressed expeditionary capabilities directly, particularly if an expeditionary force is defined using the U.S. Department of Defense definition as "an armed force organized to accomplish a specific objective in a foreign country."41 The Chinese operational concepts being tested in joint exercises are focused on operations involving Taiwan or contingencies on China's borders. In many respects, these operational concepts reflect longterm thinking about two of China's most significant potential conflict scenarios: Taiwan-centered operations and "chain reactions" along PRC's periphery. ${ }^{42}$ As China's overseas interests continue to expand, however, the need for expeditionary operations most likely will increase. Recent commentaries in official Chinese press highlight the important of overseas military operations, particularly in terms of protecting Chinese enterprises and citizens from "turbulence, terrorism, piracy, natural disasters, and epidemics." ${ }^{43}$ In addition, China's Military Strategy also outlines the need for PLA to be able to protect a variety of interests beyond China's borders.

From PLA's perspective, the skills developed during joint exercises are applicable to a range of potential future expeditionary operations. In particular, the most recent edition of Science of Strategy, published in 2013, argued that even though nonwar military activities have their own unique characteristics and guiding principles, the development of capabilities for these activities is

Chinese military press reporting makes these claims, but there is no other information available by which to verify or refute them.

${ }^{41}$ Department of Defense. Joint Publication 3-0: Joint Operations, Washington, D.C., July 11, 2011. The definition is found on p. 9 of the glossary.

42 Information Office of the State Council, 2015, p. 4.

43 "China's Overseas Military Operations Demonstrate Concept of Peaceful Development," Xinhua, July 31 , 2015; and Yu Jincui, "Overseas Evacuation Attests to Nation's Responsibility," Global Times, March 31, 2015. 
linked closely to the development of combat capabilities. ${ }^{44}$ Based on this argument, PLA joint training involving long-range mobility, local logistical procurement, and adapting to new operational environments is translatable to future operations to secure and protect PRC citizens and interests overseas. In line with new strategic concerns, PLA has placed increasing emphasis on developing new capacity within the PLAN Marines, People's Armed Police Special Forces, and PLAAF's 15th Airborne Corps. ${ }^{45}$ The PLAN Marines have been involved in multiple longrange mobility exercises designed to build their capabilities in multiple environments. Similarly, a small contingent of People's Armed Police Special Forces performed training in Sri Lanka that addressed "single-soldier counterterrorism techniques, small group tactics, and combat training methods" among other subjects. Lastly, the PLAAF $15^{\text {th }}$ Airborne Corps has developed a relationship with Russia's Airborne Forces which seeks to build joint training and academic exchanges. ${ }^{46}$

When considered with long-term PLAN counterpiracy deployments and in the context of these organizations' participation in joint exercises, these examples indicate that in an emergency or crisis situation, PLA likely would have some capacity to consider responding to an overseas contingency, even in the absence of an explicit classification of those activities as expeditionary. While PLA's expeditionary capabilities remain nascent and underdeveloped, the example of PLAN deployments to the Gulf of Aden demonstrates PLA's capacity to deploy on relatively short notice, sustain extended operations, build on its experience, and implement changes based on those insights. The key question that remains is whether the experience derived from PLA's recent joint exercises would enable a successful operation requiring forced entry and sustained operations in a high-intensity, hostile environment. It seems that at this stage of development, this would be an extraordinarily difficult proposition for PLA, even under the best conditions.

Joint operation exercises in the 13th Five Year Plan will undoubtedly reflect PRC's most significant strategic concerns. The training subjects and scenarios involved in these exercises will thus be tailored to address those conflicts most central to PRC's national security interests. With Taiwan elections looming and uncertainties about the direction of the China-Taiwan relationship, there is a distinct possibility that PLA units most likely will maintain a predominant focus on training for Taiwan and regional border contingencies. However, as China's Military Strategy recognizes and recent threats to Chinese citizens in the Middle East demonstrate, PLA leaders

\footnotetext{
${ }^{44}$ Shou, 2013, p. 86.

45 "PAP Special Operations Personnel Participate in Joint Training in Sri Lanka for the First Time," Jeifangjun Bao, June 22, 2015; Chen Guoquan, et al. "The 'Mighty Dragon at Sea' Withstands the Major Test of All-Area Operations: An Account of the First Cross-Region Movement and Cold Region Training of the Marine Corps of the PLA Navy with a Complete Unit," Jeifangjun Bao, March 21, 2014; and "Airborne Troops Beef Up Combat Capability in Long-Distance Airborne Drill," Jeifangjun Bao, April 22, 14.

46 "Ma Xiaotian Meets with Russian Guests," Jeifangjun Bao, May 28, 2014.
} 
and planners might be compelled to respond to intensified threats against Chinese citizens from terrorist organizations and related political instabilities that could harm PRC corporations and interests. If these threats materialized, the nature of PLA joint operation training would almost surely expand its scope to dealing directly with building the expeditionary capabilities tailored toward this new set of security concerns. 